\title{
HONRA AO MÉRITO
}

Há vinte e sete anos, por iniciativa dos Professores do Cursc de Letras, surgia a revista Letras.

Nas palavras de apresentação daquele primeiro número, diża - Professor Homero Baptista de Barros que a publicação não se "destinava apenas a perpetuar a messe de fúlgidas inteligência", "ao intercâmbio de pensamentos sempre valiosos para as me'hores conquistas do saber" mas também "à guarda do idioma nacional, como instrumento mantenedor de nossas tradiçōes".

A revista se desenvolveu durante esses anos à sombra de Rosário Farâni Mansur Guérios, que soube zelar pelo idioma nacional com sabedoria, dignidade e modéstia.

Desejando os amigos e ex-discípulos expressar a reverente admiração e gratidão ao ilustre mestre de tantas geraçõas, dedicam-lhe este número.

E mesmo um dever cívico chamar para a obra de Mansur Guérios o reconhecimento dos pósteros, testemunhar e proclamar que ele foi um mestre que lembra os ideais da sabedoria clássica e serviu à sausa do ensino e da pesquisa. 


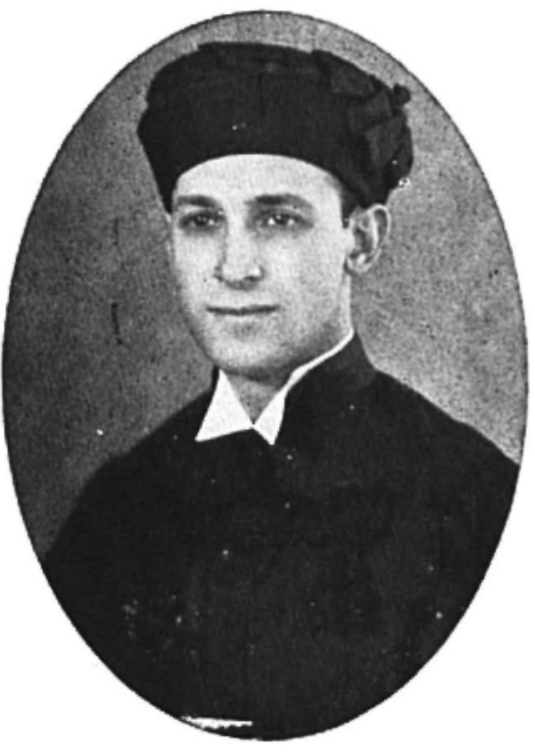

O HOMENAGEADO

PROFESSOR ROSÁRIO FARÂNI MANSUR GUERIOS 


\title{
O MAGO
}

\author{
Ao Mestre, ao Amigo, ao Mago, \\ Mansur Guérios
}

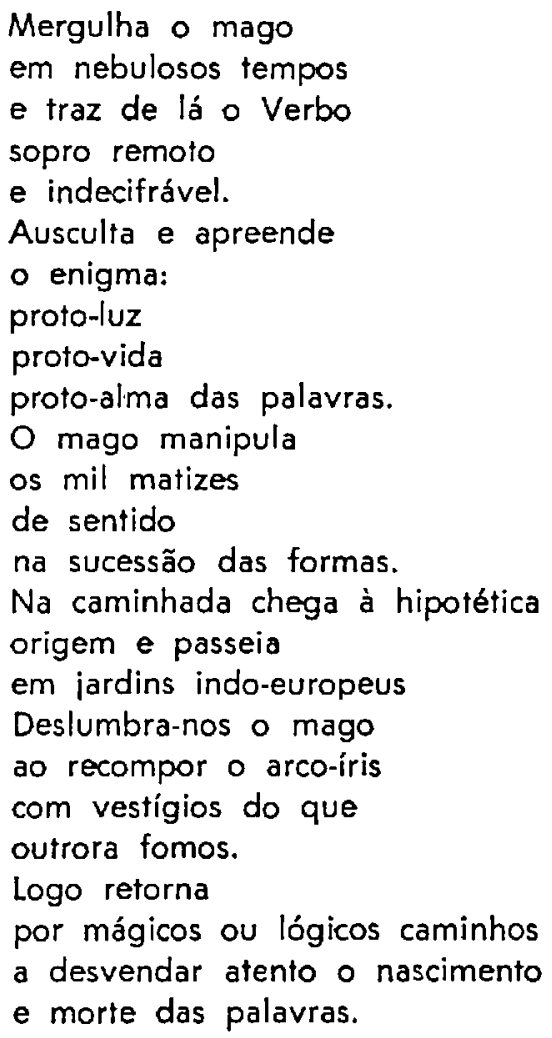

Juril do Nascimento Campelo 


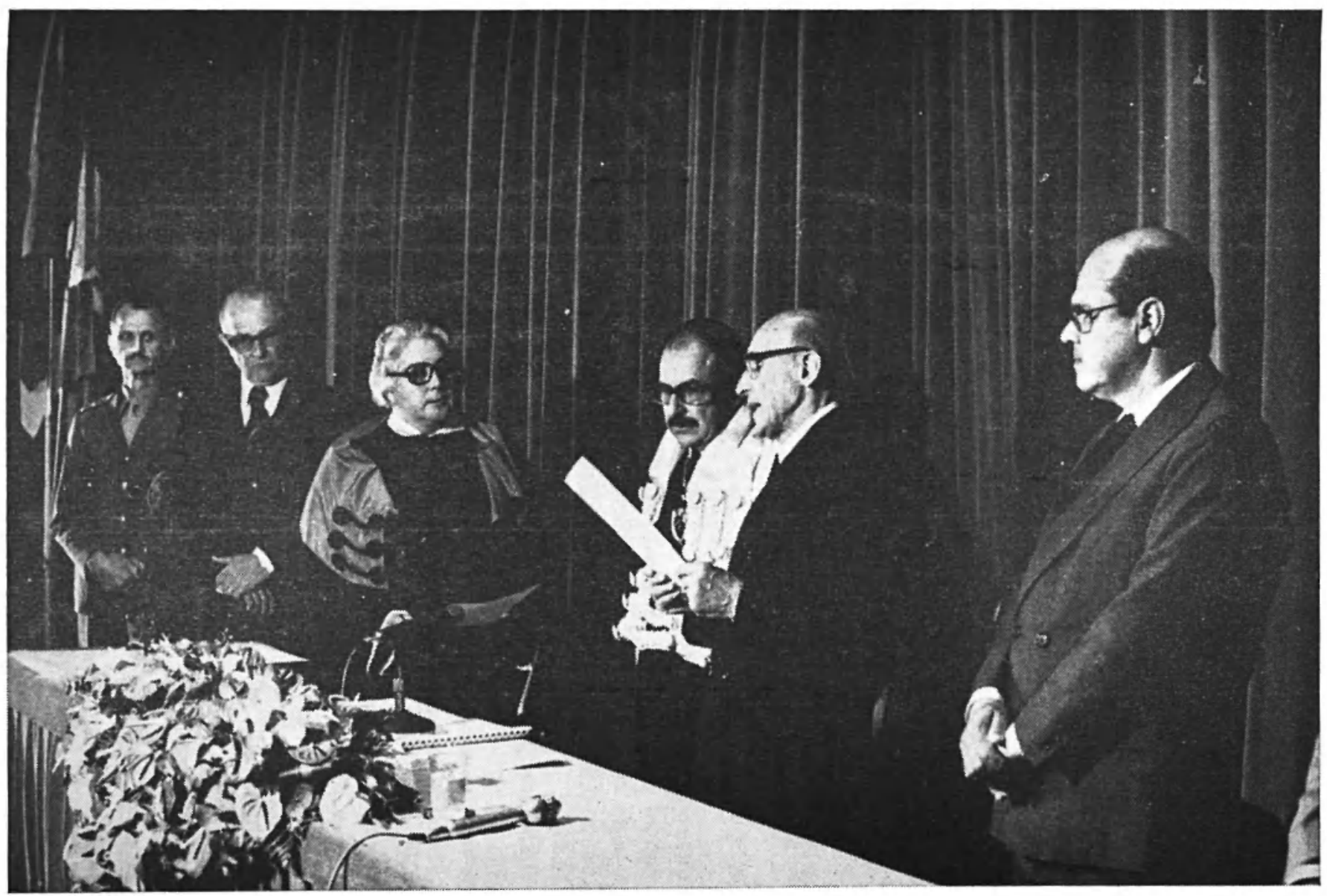

A ENTREGA DO TÍTULO DE PROFESSOR EMÉRITO PELO MAGNIFICO REITOR 